\title{
1. Authority, solid and liquid, in postnational governance
}

\section{Nico Krisch*}

\section{INTRODUCTION}

Governance beyond the state comes in many guises; hard and soft, concentrated and dispersed. Formal decision-making and binding rules stand alongside a panoply of more informal instruments, such as soft law, rankings, assessments, guidelines and best practices, many of them emerging from interactions between different institutions and their weight shifting over time, depending on their connection with key societal, economic or governmental actors. Many of these informal instruments are highly influential and have a significant impact on their addressees the OECD's PISA study, for example, has triggered or boosted educational reform in a number of countries; the Basel Committee's standards on banking regulation have led to adjustments by many national financial regulators; Standard \& Poor's credit ratings have helped to bring several governments to the brink of financial collapse. Yet while such instances are typically seen as instances of 'governance', they are usually not regarded as 'authority' properly understood - they appear as too soft, too indeterminate, too dispersed, too dependent on social processes to count as such.

* Earlier versions of this chapter were presented at the Institut Barcelona d'Estudis Internacionals (IBEI); the University of Oxford; Goethe University Frankfurt; Queen Mary University of London; the Hertie School of Governance, Berlin; Pompeu Fabra University, Barcelona; and the University of Amsterdam. The author wishes to thank the participants in these events as well as Roger Cotterrell, Benedict Kingsbury, Kate and Terry Macdonald, Maksymilian Del Mar, Ole Jacob Sending, Neus Torbisco Casals and Michael Zürn for their comments; Loh Yuh Yiing and Tània Foix Pericot for their valuable research assistance; and the IBEI as well as the Hertie School of Governance for their support of the project. 
In most contemporary accounts of postnational governance, 'authority' is conceived in rather narrow terms. Their focus is on 'solid' authority binding powers and the creation of formal obligations - in analogy to domestic, governmental authority, and many of them highlight the expansion of such solid authority in an international context in which it has long been regarded as (mostly) absent. Such accounts take into view the rise of law-making by the UN Security Council, the proliferation of mandatory dispute settlement mechanisms, or generally the increase in delegation to international organizations. They capture an undoubtedly important development, and they help to counter the dominant portrayal of international politics as 'anarchical'. 1

This focus on 'solid' authority reproduces the imagery of bureaucratic authority in the modern state, but it obscures from view many of the 'softer' phenomena mentioned in the beginning, and thereby it also risks relegating them to a sphere of lesser importance. This is problematic because it shifts attention elsewhere even if they often have a similar, or indeed stronger, impact than their solid counterparts - it makes us focus on the traditional, compulsory face of power and lose sight of other, less apparent yet at times more intrusive forms. This underestimates the extent of authority in the global realm and it leads to misconceptions about its nature, visible especially in questions of accountability and legitimacy, which present themselves in a very different light for the less solid settings of the postnational world. Framing authority in a solid vein risks making us see primarily those parts of global governance that resemble the structures of the modern state, and it leads us to develop responses in statist terms that are inadequate for the very different world of the postnational.

In this chapter, I begin by reconstructing the dominance of the solid authority model in accounts of international order and global governance and highlight their limitations (section II). I then suggest an alternative, broader conceptualization of authority that includes 'liquid' elements as well. This conceptualization follows domestic theories of authority that are inspired by sociological observations, and it picks up different recent attempts at loosening the boundaries of 'authority' in contemporary discourses around international and transnational legal and political practices (section III). In this new picture, many instances of authority

1 DA Lake, 'Rightful Rules: Authority, Order, and the Foundations of Global Governance' (2010) 54 International Studies Quarterly 587; M Zürn, M Binder and M Ecker-Ehrhardt, 'International Authority and Its Politicization' (2012) 4 International Theory 69. 
are characterized by informality, substantive rather than formal groundings, institutional multiplicity and significant dynamism. Reconceiving authority in this way not only captures a broader part of consequential practices in global governance; it also paves the way for asking harder questions about, and developing more calibrated approaches to, questions of law, legitimacy and accountability in this context (section IV). Liquid authority is far more difficult to trace, comprehend and hedge than its solid counterpart, and the conceptual shift advocated here forces us to confront this difficulty in a more direct and focused fashion. This should not only make us question the traditional mental maps with which we approach authority beyond the state; it should also help us to gain a clearer view of the particular problématique of analysing, and hedging, postnational governance.

\section{SOLID AUTHORITY AND ITS LIMITATIONS}

\section{IIA. The Idea of Authority in International Thought}

Authority is a key concept in politics and law, but in the international realm it has long been present mainly through its absence. For many scholarly observers, it was precisely the lack of 'authority' - understood in a sociological, not a normative $\operatorname{sense}^{2}-$ that defined the structure of the international system and led to its anarchical character. In many ways, such accounts followed in the tracks of Thomas Hobbes's depiction of international life as remaining in a state of nature. ${ }^{3}$ For the most part, the contrast modern theorists drew between (international) anarchy and (domestic) authority relied on a conception of authority focused on a central 'government' equipped with binding powers and enforcement tools. ${ }^{4}$ As Kenneth Waltz put it in his seminal account of international politics:

2 In this chapter, I focus on sociological notions of authority - as the ability of an actor to induce deference in others, as I will explain below. I do not take into view normative notions of authority, for example the question as to whether an actor has the right to rule others. In Joseph Raz's terminology, I am interested here in de facto authority, not in legitimate authority, even though, as will become clear, I differ from Raz in his account of authority. See J Raz, 'Authority and Justification' (1985) 14 Philosophy \& Public Affairs 3, 5.

3 D Armitage, Foundations of Modern International Thought (Cambridge, Cambridge University Press, 2013) ch 4.

4 H Milner, 'The Assumption of Anarchy in International Relations Theory: A Critique' (1991) 17 Review of International Studies 67. 
National politics is the realm of authority, of administration, and of law. International politics is the realm of power, of struggle, and of accommodation. ... The national realm is variously described as being hierarchic, vertical, centralized, heterogeneous, directed, and contrived; the international realm, as anarchic, horizontal, decentralized, homogeneous, undirected, and mutually adaptive. ${ }^{5}$

Authority here is formal, binding and hierarchical - and stands in clear opposition to what is perceived to be the structure of international affairs. Other, less solid forms of governance and governing remain out of the picture; they are seen as peripheral.

Since the turn of the millennium, the tide has turned somewhat, and many observers have pointed to a significant rise in international authority. Ian Hurd, for example, paints a picture of international politics 'after anarchy' as a consequence of the emergence of legitimate authority in international organizations. ${ }^{6}$ Yet for many contemporary accounts of authority in the international realm, the notion of authority remains the same as in earlier times: it remains bound up with formal, binding powers. What has changed is the extent to which such quasigovernmental authority can be found beyond the state. David Lake, in one of the most prominent contributions, sums his conception of authority up as follows:

When political authority is exercised, the governor, A, commands a set of subordinates, or the governed, B, to alter their actions, where command implies that A has the right to issue such orders. ${ }^{7}$

Lake's notion of authority thus remains focused on 'solid' expressions: on commands and binding rules issued by an identifiable governor (or governing institution) over those subject to his or her rule. Similar approaches are common among students of authority in international politics. Scott Cooper and his colleagues, for example, see international institutions as having authority "when states recognize, in principle or in practice, their ability to make legally binding decisions', and they proceed to an examination of the factors and mechanisms behind the

5 KN Waltz, Theory of International Politics (Reading, Addison Wesley, 1979) 113.

6 I Hurd, After Anarchy: Legitimacy and Power in the United Nations Security Council (Princeton, Princeton University Press, 2008) 60-4.

7 Lake 2010, above n 1, 591. 
creation of such authority. ${ }^{8}$ Liesbet Hooghe and Gary Marks, in their broad attempt to measure and explain international authority, draw explicitly on Lake for their conceptualization and then focus solely on legal authority - the formal delegation or pooling of decision-making powers. ${ }^{9}$ Informal and softer forms of governance, here again, are on the sidelines.

This solid model of authority has roots in traditional imaginations of the modern state and owes much to Max Weber. For Weber, both Herrschaft and Autorität are tightly connected to hierarchical relations of superiors and subordinates and to commands and rules that are intended to trigger compliance. ${ }^{10}$ This general focus reflects a typical modern preoccupation with compulsory forms of power at the expense of other faces of it, ${ }^{11}$ and it has influenced thinking about authority not only in political science and sociology but also in political philosophy. For Tom Christiano, for example, political de facto authority requires the ability of the state to 'compel' those who do not wish to go along with its directives, and his three alternative conceptions of political authority - as justified coercion, as the capacity to create duties of subjects, and as a right to rule - all imply clear hierarchies and typically a reliance on commands. ${ }^{12}$ And with a view to the international realm, Allan Buchanan and Robert Keohane formulate their approach in similar terms: '[i]f I acknowledge an institution as having authority, I thereby acknowledge that there are content-independent reasons to comply with its rules or at least to not interfere with their operation.' The institutions they have in mind are 'like governments in that they issue rules and publicly attach significant consequences to compliance or failure to comply with them'. ${ }^{13}$

In legal philosophy, the object of discussions around authority concerns the authority of law and legal rules rather than that of particular institutions. A tendency towards the 'solid' in this area, just as in political

8 S Cooper et al, 'Yielding Sovereignty to International Institutions: Bringing System Structure Back In' (2008) 10 International Studies Review 501, 505.

9 L Hooghe and G Marks, 'Delegation and Pooling in International Organizations' (2015) 10 Review of International Organizations 305.

10 Max Weber, Wirtschaft Und Gesellschaft, 5th edn (Tübingen, Mohr Siebeck, 1980) 544.

11 S Lukes, Power: A Radical View, 2nd edn (New York, Palgrave Macmillan, 2005).

${ }_{12}$ T Christiano, 'Authority' in EN Zalta et al (eds), Stanford Encyclopedia of Philosophy (Stanford, Stanford University Press, 2013) 4.

13 A Buchanan and RO Keohane, 'The Legitimacy of Global Governance Institutions' (2006) 20 Ethics and International Affairs 405, 411, 406. 
philosophy, is induced by the general focus on the justification and limits of a duty to obey on the part of the authority's subjects - such a duty can typically arise only in the context of formal, mandatory rules and obligations, not through the softer norms and instruments mentioned at the beginning of this chapter. This tendency towards solidity is exacerbated by the centrality of a legal and judicial imagery in theoretical approaches, and it finds expression in the conception of authority most widely followed in the field, that developed by Joseph Raz. For Raz, authority (both in law and beyond) centres on the imposition of duties which are meant to operate preemptively, thus displacing alternative reasons for action the subjects might have. ${ }^{14}$ In order to be a de facto authority, an actor or norm has to at least make a claim to such a preemptive effect, something that does not apply to instruments such as soft law, advice, and rankings which make up a large part of the operation of global governance and which provide their addressees with additional, not exclusionary, reasons. This restrictive approach to authority is compounded by Raz's insistence that legal systems necessarily claim supremacy, thus aiming to pre-empt other normative orders. ${ }^{15}$ Raz's conception of authority has also had much influence on contemporary accounts of authority in international law. Samantha Besson, for example, draws explicitly on Raz and sees authority as exercised through 'directives [that] are (i) content-independent and (ii) exclusionary reasons for action' for a subject. ${ }^{16}$ The resulting picture is, unsurprisingly, restricted to formal international obligations and the claims to obedience they are justified in making.

\section{IIB. Solidity and its Implications}

In world politics, the emphasis on hierarchies, commands and obligations - solid authority - leads to a narrow focus on formal rules and a particular set of institutions, characterized by legal powers to take binding decisions, a basis in formal delegation, and ideally the ability to use enforcement tools. Consequently, most accounts of authority in the global sphere revolve around a small number of bodies with particularly strong formal powers - typically the UN Security Council, the WTO

14 Raz 1985, above n 2; J Raz, 'The Problem of Authority: Revisiting the Service Conception' (2006) 90 Minnesota Law Review 1003, 1018-9.

$15 \mathrm{~J}$ Raz, The Authority of Law: Essays on Law and Morality, 2nd edn (Oxford, Oxford University Press, 2009) 118-19.

16 S Besson, 'The Authority of International Law - Lifting the State Veil' (2009) 31 Sydney Law Review 343, 351. 
Dispute Settlement Body, and the International Criminal Court. ${ }^{17}$ Some accounts extend to a broader range of mandatory dispute-settlement mechanisms or powers delegated to formal international institutions in general. ${ }^{18}$ Still, they focus on a very limited set of global governance contexts - for them, authority is still the exception in international politics, and the general image of anarchy is challenged only by a few 'islands' of authority. Attempts at reaching further - such as that of Lake who seeks to 'recognize the diverse forms of authority in world politics today' and aims at 'shedding the blinders that mask the possibility of authority between and over states' 19 - run into inconsistencies if they fail to broaden their conceptual framework.

Focusing on solid authority has important implications for understanding how international authority comes about. If authority is connected to formal powers and obligations, it takes a noticeably legal form and depends on processes of treaty-making for its creation. As a result, the delegation of authority by states takes centre-stage, and indeed, delegatory processes have been at the centre of recent attempts to explain the creation of authority ${ }^{20}$ and the design of institutions in world politics in general. ${ }^{21}$ Authority is then typically seen in a principal-agent framework, legal norms define much of its scope, and states remain at the core of the creation and operation of authority structures.

This has further consequences for understanding accountability structures. The more authority is seen through a principal-agent prism, the more delegatory rather than participatory accountability will be the dominant frame. ${ }^{22}$ If we proceed from a solid imagery, this also suggests using analogies with similarly solid institutional structures from the domestic realm and modelling accountability mechanisms on them. This

17 Cooper et al 2008, above n 8; I Hurd, 'Legitimacy and Authority in International Politics' (1999) 53 International Organization 379, 401-02; Christiano 2013, above n 12; Buchanan and Keohane 2006, above n 13.

18 Hooghe and Marks, above n 9.

19 Lake 2010, above n 1, 596, 591.

20 Cooper et al 2008, above n 8; Hooghe and Marks, above n 9.

21 CA Bradley and JG Kelley, 'The Concept of International Delegation' (2008) 71 Law and Contemporary Problems 1; DG Hawkins et al, 'Delegation under Anarchy: States, International Organizations and Principal-Agent Theory' in DG Hawkins et al (eds), Delegation and Agency in International Organizations (Cambridge, Cambridge University Press, 2006); B Koremenos, C Lipson and D Snidal, 'The Rational Design of International Institutions' (2001) 55 International Organization 761.

22 RW Grant and RO Keohane, 'Accountability and Abuses of Power in World Politics' (2005) 99 American Political Science Review 29. 
is, for example, the general thrust of the influential global administrative law project, despite its own acknowledgment of the limitations of this approach when it comes to less traditional structures. ${ }^{23}$ The focus here is on transparency, participation and review mechanisms for institutions that are conceived of as traditional, individual regulators. Similar approaches are widespread in approaches to accountability in the global realm even if they extend to institutions of an informal or private nature. ${ }^{24}$ This mirrors a statist framing, but it evades many of the complications that arise from the informal, fragmented and changeable configuration of large parts of global governance, which I will discuss below.

Questions of legitimacy, too, are often discussed with solid authority in mind. Buchanan and Keohane, for example, explicitly organize their inquiry into the legitimacy of global governance institutions around the image of institutions that are 'like governments', and delegatory processes - the consent of (democratic) states - play an important role in their broader framework. ${ }^{25}$ State consent plays an even stronger part in Tom Christiano's account of the legitimacy of international institutions. For him, legitimacy demands arise in the context of 'legitimate authority', i.e. 'the moral power to impose a set of rules by which the others must regulate their conduct', and the creation of duties is the central and hardest case of such rules. ${ }^{26}$ In international society, such intrusive acts appear to him as unjustifiable in the absence of consent by the main (democratic) actors, states. The link of legitimacy standards to the solid model becomes especially clear here: if authority were exercised in other ways than through the creation of obligations (for states), we would probably find a greater openness to considering other standards - not necessarily less demanding ones, but ones more suited to an institutional landscape less in tune with the statist image.

23 B Kingsbury, N Krisch and RB Stewart, 'The Emergence of Global Administrative Law' (2005) 68 Law and Contemporary Problems 15.

24 See, e.g., One World Trust, 'Global Accountability Report 2008' (2008) $<$ http://www.oneworldtrust.org/globalaccountability/gar/2008gar-mock>.

25 Buchanan and Keohane 2006, above n 13.

26 T Christiano, 'The Legitimacy of International Institutions' in A Marmor (ed), The Routledge Companion to Philosophy of Law (London, Routledge, 2012) 381. 


\section{BEYOND SOLIDITY}

Thinking about authority in a solid vein thus makes us see (and study) an important but small and particular part of the landscape of global governance, and it leads us to analyse, assess, and develop responses to international authority in a particular fashion, often close to models employed in the context of the modern state. This makes us 'wear blinders': 27 it obscures from view the many forms of institutional influence in global governance which, though often highly consequential, do not operate through formal, legal tools. It reproduces a focus on 'juridical sovereignty', so typical of modern, liberal thought about politics and law, and tends to obfuscate other 'techniques and tactics of domination'. ${ }^{28}$ In this, the solid model also fails to push us towards asking hard questions about how authority emerges beyond delegatory frames and how accountability can be organized if authority is not concentrated and fixed.

\section{IIIA. Limits of Solidity in the Domestic Realm}

The solid imagery of authority is a product of the historical particularity of the modern state. The expansion and consolidation of formal-legal bureaucracy in the development of government in industrial states, in many ways the focus of Weber's conception of authority, contrasts starkly with forms of authority in other social spheres and historical epochs. In the Middle Ages, in particular, political authority was characterized by fragmentation and competition, most clearly on display in the investiture contest between popes and monarchs over the power to appoint the clergy. As Frank Furedi notes, '[i]n the medieval era the construction of authority co-existed with its contestation. ... The very character of such contestation encouraged a cycle of claims and counter-claims that would eventually expose the assertion of any authority to unprecedented scrutiny'. ${ }^{29}$ In medieval Italian cities, as Weber himself noted, 'numerous claims to authority [stood] side by side, overlapping and often conflicting

\footnotetext{
27 Lake 2010, above n 1, 591.

28 M Foucault, Power/Knowledge: Selected Interviews and Other Writings, 1972-1977 (New York, Pantheon, 1980) 102.

29 F Furedi, Authority: A Sociological History (Cambridge, Cambridge University Press, 2013) 123.
} 
with each other'.30 Secular and ecclesiastical authority were in competition, public and private authority not clearly distinguished, different sources of power and authority coexisted, all of which led to a multiplicity of authorities vying for influence and allegiance.

If such multiplicity was reduced by the emergence of strong, central state institutions with enforcement powers, it never disappeared entirely and remained, to different degrees, characteristic of most societies. Theorists of legal pluralism have traced the effects of multiple layers of law in traditional, postcolonial as well as modern industrialized contexts, highlighting the interactions - both cooperative and conflictual - between different legal orders and their institutions. ${ }^{31}$ They turn their gaze beyond state institutions and formal law and highlight the problematic and porous distinction between state and society, long noted by theorists of the state outside the Neo-Weberian tradition. ${ }^{32}$ Thus for many contemporary sociologists political authority is merely formally concentrated in bureaucratic institutions but in fact is continually constructed and reconstructed through complex interactions between social actors in which state institutions have an important, but not an exclusive, role. ${ }^{33}$ Outside the political-administrative realm, authority anyway comes in a variety of forms, with varying degrees of solidity and consolidation in contexts such as the family, schools, churches, or the workplace.

Postmodern theorists have radicalized these insights and diagnosed 'an extreme fragmentation of the sites of authority' as a consequence of the rationalization and differentiation of society. ${ }^{34}$ Very much in contrast with formal appearances and the image of solidity, authority in contemporary societies is seen by many today as inevitably 'various and diffuse'. ${ }^{35}$ This state of affairs is only enhanced, in the political realm, by the turn to governance, with its emphasis on collaboration, soft steering and publicprivate networks, in which formal-legal authority gives way to informal

30 M Weber, Economy and Society: An Outline of Interpretive Sociology (Berkeley, University of California Press, 1978) 1251.

31 SE Merry, 'Legal Pluralism' (1988) 22 Law and Society Review 869.

$32 \mathrm{~J}$ Bartelson, The Critique of the State (Cambridge, Cambridge University Press, 2001).

33 N Fligstein and D McAdam, A Theory of Fields (Oxford, Oxford University Press, 2012).

34 Z Bauman, Legislators and Interpreters: On Modernity, Post-Modernity and Intellectuals (Oxford, John Wiley \& Sons, 2013) 188.

35 N Rosenblum, 'Studying Authority: Keeping Pluralism in Mind' in $\mathrm{R}$ Pennock and J Chapman (eds), NOMOS XXIX: Authority Revisited (New York, New York University Press, 1987) 103. 
instruments. ${ }^{36}$ Attuning authority to such forms also recognizes the fact that much non-bureaucratic authority is exercised not through commands - in a potential clash with the interests of their addressees - but instead through invocations of what is right to do, appealing to (and changing) the addressees' self-understanding. ${ }^{37}$

The shift towards a postnational constellation in which authorities of various kinds proliferate at different levels - many of them operating in modes other than commands - may then present not so much a break with authority in the domestic context, but rather a continuation, and an exacerbation, of the pluralistic features of authority in domestic society, with an interaction of multiple sites and kinds of authority the chief characteristic.

\section{IIIB. Broader Approaches in the Postnational Context}

In the postnational context, a broader understanding of authority slowly gained ground since the end of the Cold War. Beginning with relatively isolated attempts, ${ }^{38}$ this trend gathered pace around the turn of the millennium, mainly in reaction to the rise of private structures of governance in the global economy. By highlighting the 'authoritative' nature of these structures in their respective spheres of operation, these accounts challenged the typical public associations of the notion of authority as well as its hierarchical implications. Private forms of regulation in areas as diverse as financial governance, the lex mercatoria, the credit-rating sector, online commerce and international mineral markets were taken into view, and the focus shifted from single 'authorities' to authority structures often composed of a variety of actors, sometimes including public ones. ${ }^{39}$

Other approaches began to include a wider range of authority forms in public institutions. These encompassed informal norms, 'moral' authority as well as epistemic, ideational or discursive tools. Practices such as

36 RAW Rhodes, 'Waves of Governance' in D Levi-Faur (ed), The Oxford Handbook of Governance (Oxford, Oxford University Press, 2012).

37 S Lukes, 'Perspectives on Authority' in J Raz (ed), Authority (Oxford, Blackwell, 1990); Lukes 2005, above n 11, 35-7.

38 JN Rosenau, 'The Relocation of Authority in a Shrinking World' (1992) 24 Comparative Politics 253.

39 AC Cutler, V Haufler and T Porter, Private Authority and International Affairs (New York, SUNY Press, 1999); RB Hall and TJ Biersteker (eds), The Emergence of Private Authority in Global Governance (Cambridge, Cambridge University Press, 2002); S Sassen, Territory, Authority, Rights: From Medieval to Global Assemblages (Cambridge, Cambridge University Press, 2006). 
rankings by the OECD, UN interventions in public debates, or the construction of legal reference points by international tribunals were now seen as exercises of authority. ${ }^{40}$ Likewise, the multiplication of authorities in the global realm came into clearer focus, for example in analyses of competition of financial regulators at different levels for a share of the 'regulatory space' 41 or in the reconstruction of the normative relations of a plurality of 'authorities' in the international realm. ${ }^{42}$

These initiatives paved the way for broader attempts at recasting the notion of authority beyond coercion and commands. ${ }^{43}$ From a legal perspective, a Heidelberg-based project on 'international public authority' conceives of authority as 'the legal capacity to determine others and to reduce their freedom, i.e. to unilaterally shape their legal or factual situation'. ${ }^{44}$ This approach, slightly modified at a later stage, ${ }^{45}$ draws on analogies from domestic public law and takes as a starting point the effects of institutional action on the individual or collective autonomy of its addressees. It extends to both binding and non-binding forms and to public as well as private institutions, even though the latter only qualify as 'public' authority under certain conditions.

While this understanding focuses on the position of the authority - its unilateral capacity - other approaches, especially those advanced by international relations scholars, have focused more on the relational

40 A von Bogdandy and M Goldmann, 'The Exercise of International Public Authority through National Policy Assessment - The OECD's PISA Policy as a Paradigm for a New International Standard Instrument' (2008) 5 International Organizations Law Review 241; M Ecker-Ehrhardt, "But the UN Said So ...": International Organisations as Discursive Authorities' (2012) 26 Global Society 451; I Venzke, 'Between Power and Persuasion: On International Institutions' Authority in Making Law' (2013) 4 Transnational Legal Theory 354.

41 J Black, 'Constructing and Contesting Legitimacy and Accountability in Polycentric Regulatory Regimes' (2008) 2 Regulation \& Governance 137.

42 N Roughan, Authorities: Conflicts, Cooperation, and Transnational Legal Theory (Oxford, Oxford University Press, 2013); see also Roughan, this volume. 43 B Peters and J Karlsson Schaffer, 'Introduction: The Turn to Authority beyond States' (2013) 4 Transnational Legal Theory 315; H Enroth, 'The Concept of Authority Transnationalised' (2013) 4 Transnational Legal Theory 336.

44 A von Bogdandy, P Dann and M Goldmann, 'Developing the Publicness of Public International Law: Towards a Legal Framework for Global Governance Activities' (2008) 9 German Law Journal 1375, 1381-2.

45 A von Bogdandy and I Venzke, 'In Whose Name? An Investigation of International Courts' Public Authority and Its Democratic Justification' (2012) 23 European Journal of International Law 7, 18. 
aspect that connects authorities and their addressees. They frame authority as 'the ability to induce deference in others' 46 or as 'deference of one's own judgment and choice to a recognized authority without being necessarily forced or persuaded to do so' ${ }^{47}$ Similar accounts emphasize the social dimension of deference as the product of a 'discursive construction in which past practices support a social expectation that B should do as A says'. ${ }^{48}$

\section{IIIC. Authority, Recognition, and Deference}

These latter approaches connect with conceptions of authority on the domestic level which have - often from a sociological background focused on deference in a wide variety of settings, public and private. ${ }^{49}$ Such approaches have been able to capture the above-mentioned historical and societal emanations of authority that state-centric accounts of legal-bureaucratic authority have avoided. And they extend to forms of theoretical authority, which - unlike practical authority - make claims on the beliefs, rather than the conduct, of their addressees. ${ }^{50}$

The emphasis in these approaches on the 'ability to induce deference' has kept the concept broad yet distinct from other forms of power or influence, thus heeding Hannah Arendt's call for authority to be defined 'in contradistinction to both coercion by force and persuasion through arguments'. ${ }^{51}$ Deference presupposes a certain degree of freedom to act otherwise, thus excluding open coercion as well as forms of structural or productive power that shape subjectivities on a deeper level. It also implies a certain content-independence - a 'surrender of judgment' - that contrasts with acts that result from substantive persuasion. However, deference does not have to be a conscious choice: addressees do not need to be aware of alternatives, both in terms of action and belief, in order to accept someone else's guidance. ${ }^{52}$

46 DD Avant, M Finnemore and SK Sell, 'Who Governs the Globe?' in D Avant, M Finnemore and S Sell (eds), Who Governs the Globe? (Cambridge, Cambridge University Press, 2010) 9.

47 Zürn, Binder and Ecker-Ehrhardt 2012, above n 1, 86.

48 Venzke 2013, above n 40, 372.

49 RB Friedman, 'On the Concept of Authority in Political Philosophy' in Raz (ed), Authority 1990, above n 37 ; RE Flathman, The Practice of Authority: Authority and the Authoritative (Chicago, University of Chicago Press, 1980).

50 Friedman 1990, above n 49, 59.

51 H Arendt, Between Past and Future: Eight Exercises in Political Thought (London, Penguin, 1968) 93.

52 Lukes 1990, above n 37, 213-4. 
Authority, in this understanding, forms part of a relation that is broader than a mere one-off exercise of power - the ability to induce deference rests on a (logically prior) recognition of an actor or process as authoritative. ${ }^{53}$ Authority then is not merely an ad hoc relation but is characterized by its systemic character. ${ }^{54}$ The recognition of authority can flow from many sources: it can result from rational calculus and be 'reflexive' in the sense of a considered choice, ${ }^{55}$ but it can also be based on normative internalization or a mere acceptance as 'normal'. It may be grounded in social legitimacy - a favourable normative assessment among its subjects - but it can just as well rely on self-interest or normalization through tradition. ${ }^{56}$

The recognition of an authority may be based on an attitude or act of the individual subject, such as delegation, but it will often bear a social dimension, both as regards the act or attitude of recognition and the terms on which recognition is based. These terms will often relate to shared values and beliefs, ${ }^{57}$ though they may themselves be the result of authority relations and power structures. ${ }^{58}$ As a result, authorities are typically recognized as such through a social practice that does not necessarily reflect the particular attitude of each of their addressees. ${ }^{59}$ For an individual actor, deference to an authority may well seem involuntary if the authority is based on a recognition by other social actors who impose costs (or withhold benefits) in cases of non-compliance. The result is a triangular structure: an actor (authority) holds the ability to

53 Friedman 1990, above n 49, 63-71.

54 A Marmor, 'An Institutional Conception of Authority' (2011) 39 Philosophy \& Public Affairs 238.

55 M Zürn, 'From Constitutional Rule to Loosely Coupled Spheres of Liquid Authority - a Reflexive Approach', manuscript on file with the author.

56 Some - like Roughan, in this volume - believe that the link with legitimacy is the distinguishing characteristic of authority, and that without this characteristic authority collapses into power (Roughan, pp. 291-293). In the account presented here, authority is a form of power, yet distinguished by the fact that it operates 'at one remove', based on the social recognition of an actor as authoritative. It is not necessary that this recognition be based on a particular set of reasons (such as normative acceptance), and in fact most authorities will be recognized for a variety of motives.

57 Friedman 1990, above n 49.

58 OJ Sending, 'Recognition and Liquid Authority', manuscript on file with the author.

59 PM Blau, 'Critical Remarks on Weber's Theory of Authority' (1963) 57 American Political Science Review 305, 312; Venzke 2013, above n 40, 366. 
induce another actor's (addressee's) deference as a result of a recognition by the addressee which rests on an individual attitude or a social practice.

\section{TOWARDS LIQUID AUTHORITY}

Broadening our conception of authority beyond the solid model brings into view a range of otherwise excluded practices and structures - many of which reflect the more peculiar features of global 'governance' - the ones that actually distinguish it from 'government'. ${ }^{60}$ Softer forms enter the picture; authority can more easily be understood as coming in degrees, rather than in absolutes; and we can better grasp sources of recognition that are not based on formal legal empowerment. Inevitably, the resulting picture of authority is far more complex than in classical accounts - apart from the few solid structures that exist in the global realm, it will also include 'liquid' ones - liquid in the sense that they are able to flow and are thus more difficult to grasp, though not for that matter necessarily less weighty or impacting. ${ }^{61}$

Liquidity, as I understand it here, is an attribute of individual authorities, but even more so of the overall authority structure in which multiple actors may occupy positions of authority with varying degrees of stability and consolidation. It is characterized by four main features: the use of informal rather than formal and binding means; the reliance on substantive rather than formal resources as grounds of authority; a multiplicity of actors instead of a unitary or focal authority; and a dynamic rather than stable nature of authority constellations. The more these elements are present in a given governance context, the more we can understand the authority structure as liquid. This implies that solidity and liquidity are ideal types and best conceived as endpoints on a continuum - the character of most authority will lie somewhere between the poles. Not all of the four elements will always be present simultaneously, and they will come in different degrees, making the authority structures in a given area more or less liquid. Yet the contrast between both ideal types should provide us with an instrumentarium to account for variation and to confront the particular challenges liquidity poses.

Liquid authority is not an altogether new phenomenon, or one that should be thought of as confined to the postnational realm. Historically,

60 JN Rosenau and EO Czempiel (eds), Governance without Government: Order and Change in World Politics (Cambridge, Cambridge University Press, 1992).

61 'Liquid', Wikipedia (2014) <http://en.wikipedia.org/wiki/Liquid>. 
as I have suggested in the previous section, most instantiations of authority have taken a more or less liquid form, and it has only been in the past few centuries that political authority has been imagined as solid, somewhat in the image of Hobbes's Leviathan. It is far from clear that this image has ever been accurate even in the domestic context; certainly today, the actual operation of authority is unlikely to be best described with the solid model. One does not need to subscribe to a vision of an entirely 'liquid modernity' 62 in order to recognize the complexity, contestation and negotiation of authority in contemporary politics and society. ${ }^{63}$ Globalization, and the new 'assemblages' of territory, authority and rights it has spurred, ${ }^{64}$ may have enhanced those features, but it has not brought them about in the first place.

\section{IVA. Four Elements}

The most widely recognized of the four elements of liquidity is informality. If solid authority functions through commands or collectively binding decisions, it contrasts with informal modes of ordering that operate through soft law, recommendations, best practices, indicators, or policy dialogues without a claim to create obligations for their addressees. ${ }^{65}$ Yet it is such modes that make up a large part of the practice of global governance. The UN Security Council with its strong law-making powers may be evocative for its similarity to domestic government, but it remains highly exceptional in the global realm. Instead, informal norms are key to governance in many issue areas, ranging from finance to environmental affairs. ${ }^{66}$ Even in areas where formal decision-making powers do exist, institutions often have recourse to recommendations or best practices in order not to overstretch their legitimacy resources. ${ }^{67}$ Global governance also frequently operates through ideational tools, seeking to create shared knowledge or common understandings of desirable goals, as is the case

62 Z Bauman, Liquid Modernity (Oxford, John Wiley \& Sons, 2000).

63 Furedi 2013, above n 29; Fligstein and McAdam 2012, above n 33; J Tully, Public Philosophy in a New Key, vol 1 (Cambridge, Cambridge University Press, 2009).

64 Sassen 2006, above n 39.

65 Besson 2009, above n 16.

66 J Pauwelyn, R Wessel and J Wouters (eds), Informal International Lawmaking (Oxford, Oxford University Press, 2012).

67 M Heupel, 'Combining Hierarchical and Soft Modes of Governance: The UN Security Council's Approach to Terrorism and Weapons of Mass Destruction Proliferation after 9/11' (2008) 43 Cooperation and Conflict 7. 
for many indicators developed in international and transnational institutions. ${ }^{68}$ Such informality does not, however, dissolve into mechanisms of persuasion: it typically relies on deference on the basis of a contentindependent recognition of the importance of their source. For example, the norms elaborated by the Basel Committee on Banking Supervision formally mere recommendations to domestic regulators - owe their influence to the fact that the Committee has established a key position in financial regulation, due in part to the market power and expertise of its members. ${ }^{69}$ Yet if this is (highly consequential) authority, it comes in a softer form than commands.

The second distinctive feature of liquidity is a tendency to rely on a substantive grounding of authority. Political authority of a solid kind is typically of a rational-legal nature, tied to formal law and bureaucracy, and traceable domestically to constitutions, internationally to delegation through treaties. Yet the more informal side of global governance informal institutions, government networks, private and hybrid authorities - often has no, or only a limited, grounding in delegation. Instead, in order to establish itself and gain recognition, it has recourse to more substantive sources: expertise, moral principles and values, or problemsolving capacity. ${ }^{70}$ Formal institutions, too, will often make such claims to complement their rational-legal authority and to strengthen their autonomy from their principals. ${ }^{71}$ We may understand this development as part of a broader trend towards epistemocratic or 'reflexive' authority in contemporary politics, ${ }^{72}$ though it is likely to be especially strong in the global context. ${ }^{73}$ Authority on such grounds is often harder to locate than its rational-legal counterpart, simply because it does not operate on the basis of explicit and public foundations. It will also often be more vulnerable to societal challenge: for example, if authority rests mainly on

68 KE Davis et al (eds), Governance by Indicators: Global Power through Classification and Rankings (Oxford, Oxford University Press, 2012); JG Kelley and BA Simmons, 'Politics by Number: Indicators as Social Pressure in International Relations' (2015) 59 American Journal of Political Science 55.

69 H Davies and D Green, Global Financial Regulation: The Essential Guide, 2nd edn (Oxford, John Wiley \& Sons, 2013).

70 Avant, Finnemore and Sell 2010, above n 46, 12-14.

71 M Barnett and M Finnemore, Rules for the World: International Organizations in Global Politics (New York, Cornell University Press, 2004) 20-31.

72 T Ball, 'Authority and Conceptual Change' in J Pennock and J Chapman (eds), Authority Revisited (New York, New York University Press, 1987); Zürn, above n 55.

73 D Kennedy, 'Challenging Expert Rule: The Politics of Global Governance' (2005) 27 Sydney Law Review 5. 
a claim to moral leadership, it may vanish quickly if efforts at discreditation succeed.

The third element of liquidity, facilitated by the first two, is multiplicity. Solid authority is often thought of as unitary, yet deference may well be granted to a variety of institutions. Authority may then become 'relative' not only in the sense that it comes in degrees, but also that it becomes relative to others - that the authority of one institution can only be conceived in its interplay with others. ${ }^{74}$ Such a pluralization occurs already through the disaggregation of authority formerly concentrated in the state, ${ }^{75}$ and it is enhanced in the regime complexes that are characteristic of many issue areas in global governance and display different degrees of 'viscosity'. ${ }^{76}$ Multiplicity is on display already in the pluralist structure of the formal legal order in the postnational realm, ${ }^{77}$ and it is further facilitated through informality and the turn to substantive authority, both of which lower the threshold for the emergence of authority. In circumstances of multiplicity, the elaboration, specification and application of norms occurs in the (sometimes harmonious, sometimes conflictive) interaction of various institutions and actors, without a formal frame or distribution of powers, and with the weight of individual contributions determined through fluid, social processes of recognition. ${ }^{78}$ Efforts at orchestration may mitigate the level of friction in this process, ${ }^{79}$ yet authority will often remain dispersed and its locus difficult to pinpoint.

A fourth element of liquidity - and partly a result of the former three - is the dynamism of authority in global governance. While a solid imagery focuses on institutions created on the basis of formal treaties and equipped with identifiable powers and resources, many institutions with authority in the broader sense are much less settled, and this makes the overall authority structure less stable over time. Informal institutions and

74 Rosenblum 1987, above n 35; Roughan 2013, above n 42.

75 JN Rosenau, 'Governing the Ungovernable: The Challenge of a Global Disaggregation of Authority’ (2007) 1 Regulation \& Governance 88.

${ }^{76} \mathrm{~K}$ Raustiala and DG Victor, 'The Regime Complex for Plant Genetic Resources' (2004) 58 International Organization 277; DW Drezner, 'The Tragedy of the Global Institutional Commons' in M Finnemore and J Goldstein (eds), Back to Basics: State Power in a Contemporary World (New York, Oxford University Press, 2013).

77 N Krisch, Beyond Constitutionalism: The Pluralist Structure of Postnational Law (Oxford, Oxford University Press, 2010).

78 Black 2008, above n 41.

79 KW Abbott et al (eds), International Organizations as Orchestrators (Cambridge University Press 2015). 
government networks are established, used and recognized not only because of the relative ease and speed of their creation, but also because they can be easily and quickly dismantled if no longer desired. ${ }^{80}$ Private, self-appointed authorities may need time to become focal on a given issue, and they may soon be replaced by others. The degree to which authority is dynamic relates to the firmness of social recognition practices. As mentioned above, authority grounded in substantive claims is typically more vulnerable to societal challenge and will reflect a lower degree of consolidation, allowing for more rapid change. Multiplicity in the authority structure, with the competition for authority it frequently entails, only adds to the experience of dynamism. Institutions do seek ways to stabilize meaning in this fluid context, ${ }^{81}$ yet authority will often be in flux, and small societal shifts may have a significant impact on its broader shape. ${ }^{82}$

These four features are not individually necessary or sufficient to make an authority structure appear as 'liquid'. Informal tools may be as consequential as traditional commands; substantive groundings may be as firmly accepted as formal-legal ones; and multiplicity need not bring about liquidity when different actors are embedded in a framework of fixed relations. On the other hand, authority might be liquid without informality (e.g., when multiple, formally created bodies compete); and it might be liquid without multiplicity (when a sole authority in an issue area does not have a stable authority base). However, as shown above, those four features - common in postnational governance - tend to reinforce each other and to generally favour liquidity: we will typically find greater liquidity the more strongly they are expressed in a given issue area.

\section{IVB. Liquidity, Contestation and the Problématique of Postnational Governance}

The idea of liquid authority evokes associations with broader accounts of a 'liquid modernity', of a 'world in motion' characterized by mobility, instability, constant change and reconfiguration, the absence of firm boundaries and constraints, and the blurring of responsibility as social

80 F Vabulas and D Snidal, 'Organization without Delegation: Informal Intergovernmental Organizations (IIGOs) and the Spectrum of Intergovernmental Arrangements' (2013) 8 Review of International Organizations 193.

81 J Black, “'Says Who?" Interpretive Authority in Transnational Regulatory Regimes', forthcoming.

82 See also Cotterrell's chapter in this volume. 
structures keep being reassembled. ${ }^{83}$ Authority in the global realm - as well as in quite a few domestic settings - shares many elements of this liquidity, and this redefines the challenges we face when trying to understand and tame it.

Taking 'liquid' authority in global governance into view helps to clarify the object of analysis, critique, and of efforts at institutional design. Understanding a practice as authority typically evokes associations of greater weight, thus making it more difficult to dismiss the practice as inconsequential. It also provides a trigger for a number of follow-on questions, especially as regards accountability and legitimacy, which in contexts without 'authority' appear less pressing. ${ }^{84}$ As long as the notion of authority is confined to its solid forms, we tend to neglect the problematic features of less solid expressions, which will often remain below the radar screen. Seeing liquid forms as 'authority' in their own right instead invites greater scrutiny and a more critical engagement, which is often lacking in debates about 'governance' with its rather benign, cooperative, and technical connotations.

Drawing liquid authority into a critical spotlight is especially urgent as it tends to operate in the background, drawing little attention but from a small set of insiders and close observers. Defining best practices or producing a ranking of government capacity in this or that field does not usually make headlines; and even less so if those practices are only a small, in themselves relatively insignificant, piece of a much broader picture, the contours of which only emerge from accretion of the practices of many actors. As a result, 'in our newly globalised world, it can be hard to locate points at which allocative decisions can be politically contested' ${ }^{85}$ Liquidity tends to disguise the very fact that authority is exercised.

Two examples may illustrate this point. The UN Security Council, which is often held up as a prime example for (solid) authority in the global context, has been careful not to overstretch its powers and has, in response to significant critique of its forays into the role of a global legislator, chosen to refrain from imposition when it comes to the

83 Bauman 2000, above n 62.

84 A Hurrell and $\mathrm{T}$ Macdonald, 'Global Public Power: The Subject of Principles of Global Political Legitimacy' (2012) 15 Critical Review of International Social and Political Philosophy 553, 556; Enroth 2013, above n 43, $350-1$.

85 Kennedy 2005, above n 73, 1. 
implementation of its legislative resolutions. ${ }^{86}$ Through its CounterTerrorism Committee (CTC), it has instead turned to soft tools and best practices to suggest proper modes of capacity-building and policy change to governments facing implementation challenges. These standards, typically non-mandatory as such, are drawn from a variety of sources, including the ICAO or the Financial Action Task Force, and they are coupled with implementation assessments prepared by bureaucrats and conclusions as to the level of external technical assistance governments should seek in their implementation efforts. The largely cooperative stance of the CTC, resting in part on the authority of other standardsetters, has dissuaded much of the initial critique, but for states caught in the assessment cycles of this regime, the effects are unlikely to be weaker than they would be in a coercive frame. The shift towards greater liquidity - the informal, cooperative nature, as well as the multiplicity of norm-makers whose products are referenced and taken into account reduces entry points for contestation and resistance, and it may well be more effective in 'disciplining' and 'normalizing' states than more visible, confrontational exercises of authority. ${ }^{87}$

The locus of decision-making is yet more difficult to grasp if authority is liquefied further. Indicators are a case in point: without a claim to normativity, often based and interlinked with standards and expertise from multiple sources, they frequently have significant effects on those they address. The World Bank's Doing Business indicators are an example here: measuring the quality of business laws and related legal institutions across the globe, they are used by multilateral development banks and domestic development aid agencies for purposes of aid allocation, and in many countries, they have prompted internal benchmarking and legal reform. ${ }^{88}$ They have also provoked contestation, both from domestic political interests and transnational actors, especially from the perspective of labour rights. Yet such contestation has had to muster significant technical expertise to counter the expert assessments that had gone into the construction of the indicators. And it had to cope with the fact that the Doing Business indicators were typically used by decisionmakers in conjunction with other indicators, leading commentators to

86 Heupel 2008, above n 67; I Roele, 'Disciplinary Power and the UN Security Council Counter Terrorism Committee' (2014) 19 Journal of Conflict and Security Law 49.

87 Roele 2014, above n 86.

88 KE Davis, B Kingsbury and SE Merry, 'Indicators as a Technology of Global Governance' (2012) 46 Law and Society Review 71, 90-5. 
suggest 'that there is an upper bound on the potential impact of any effort to regulate the production as opposed to the use of indicators'. ${ }^{89}$

Among the multiple normativities in global governance, the objects of contestation keep shifting - liquid authority is dynamic, difficult to locate and thus hard to grasp for actors who seek to challenge it. In many contexts, structural and productive forms of power play a stronger role and have more durable effects - than the traditional, more clearly identifiable compulsory face of power. ${ }^{90}$ As a result, in the liquid modernity Zygmunt Bauman imagines, revolution becomes impossible because "there are no buildings where the control desks of the system are lodged and which could be stormed and captured'. ${ }^{91}$ This diagnosis may appear somewhat exaggerated - contestation does occur also in the more liquid contexts of global governance - but it points to significant limitations of contestatory practices that result from the fact that liquid authority is invariably difficult to grasp.

These limitations certainly affect the use of accountability mechanisms typically employed in the domestic context for solid forms of authority. Public participation and judicial review, for example, often suffer from the lack of a suitable target: when there is no one point of decisionmaking, but instead a continuous social process in which standards are made and remade by different actors, they will often fail to produce relevant effects. ${ }^{92}$ As a result, accountability may need 'to be understood and practised in contemporary governance in a dispersed and shared fashion', ${ }^{93}$ yet precisely how to accomplish this remains an open question. In many approaches, genuinely public accountability is replaced by the inclusion of stakeholders at different stages in the process, direct participation gives way to accountability-by-proxy, and broader input from the citizenry is reduced to forms of ex post contestation and irritation in visions of spontaneous or experimentalist accountability. ${ }^{94}$ That this often provides only a modest degree of influence shines through

89 Ibid, 94.

90 M Barnett and R Duvall, 'Power in International Politics' (2005) 59 International Organization 39.

91 Bauman 2000, above n 62, 5.

92 Kingsbury, Krisch and Stewart 2005, above n 23, 53-5.

93 JA Scholte, 'Global Governance, Accountability and Civil Society' in JA Scholte (ed), Building Global Democracy?: Civil Society and Accountable Global Governance (Cambridge, Cambridge University Press, 2011) 20.

94 J Brassett, B Richardson and W Smith, 'Private Experiments in Global Governance: Primary Commodity Roundtables and the Politics of Deliberation' (2012) 4 International Theory 367; M Koenig-Archibugi and K Macdonald, 'Accountability-by-Proxy in Transnational Non-State Governance' (2013) 26 
when it is coupled with a call to accept that the 'public control project', so central to the modern political imagination, should realistically be abandoned. ${ }^{95}$

\section{CONCLUSION}

Postnational authority comes in a different shape than that we typically associate with the notion of 'authority', or at least political authority. If authority is usually conceived of in solid terms - linked to binding decisions and obligations - in global governance it takes a more liquid form, characterized by informal tools, substantive rather than formal groundings, a multiplicity of sites rather than a unique locus, and a high degree of dynamism rather than stability and settlement.

In this chapter, I have sought to sketch these different features of liquidity, and I have made a case for recognizing liquid authority as authority proper. This case is based on a relational conception of authority, centred on recognition and deference, which accepts that the formal-bureaucratic authority characteristic of the modern state has historically been only one among many, far less consolidated, forms of authority. Domestic societies today are characterized by authorities of varying shape, and this is also true for the postnational context. Yet in the latter, the degree of liquidity is likely to be significantly higher, simply because solid authority is in short supply and efforts at establishing it often meet with contestation and rival attempts at institution-building. The consolidation of authority in postnational governance is limited, and in most areas, authority displays more or less liquid features.

Understanding liquid governance as 'authority' has a number of important repercussions, key among them the need to ask hard questions about when and how it can be made legitimate and accountable. Liquid authority poses a special challenge here as it is often difficult to identify and hard to grasp - contestation, let alone institutional accountability mechanisms, face high hurdles here. Yet we can hardly afford to ignore the challenge. Liquid authority may - like any liquid object - be flowing and of no fixed shape but it is not necessarily less weighty than its solid

Governance 499; G De Búrca, RO Keohane and C Sabel, 'Global Experimentalist Governance' (2014) 44 British Journal of Political Science 477; see also J Steffek, 'Public Accountability and the Public Sphere of International Governance' (2010) 24 Ethics and International Affairs 45.

95 KH Ladeur, 'The Emergence of Global Administrative Law and Transnational Regulation' (2012) 3 Transnational Legal Theory 243. 
counterpart. In fact, because liquidity often obscures the fact that authority is exercised, it may have more pervasive effects. Confronting the peculiar shape of liquid authority should help us gain a clearer view of the particular problématique of postnational governance, and of the challenges that lie ahead in both its analysis and development. 